\title{
The Imperatives of the Provision of Infrastructure and Improved Property Values in Nigeria
}

\author{
Udoka, Israel Sunday \\ Department of Estate Management, Akwa Ibom State Polytechnic \\ Ikot Osurua, Ikot Ekpene, Akwa Ibom State, Nigeria
}

\section{Doi:10.5901/mjss.2013.v4n16p21}

\section{Abstract}

Property development in most cases will not be attempted beyond the level of owner occupation at regions where infrastructure are not provided; talk less of property so developed having enhanced value. This research examines the imperative of infrastructural provision on property values. The research beamed its light on the relationship between property values and the development of infrastructure; the factors that influence property values; and assessing the trend of infrastructural development in Akwa Ibom State in recent past. It recommends that government should provide more infrastructure in rural areas to harness development and ginger property values; urban neighbourhoods to be landscape, with site and service schemes provided; allocate budgetary provisions adequately for the maintenance of the infrastructure; and private individual beneficiaries in the various communities where these facilities are provided to maintain sufficient security to avoid theft and vandalisation, so as to continue to improve values of properties in such domains.

Keywords: infrastructure provision, property value, neighbourhood, development, and budgetary provision.

\section{Introduction}

Infrastructural decay occasioned by the neglect by governments has bedevil most of our towns and cities in Akwa Ibom State, until recently when the present regime took over the mantle of leadership in the state by Governor Godswill Akpabio in 2007. The scenario is not perhaps totally different from what is tenable in other states of the federation.

The term infrastructure refers to all the physical, social and economic elements needed to support the population, in addition to other municipal services which include sewer, water supply, natural gas and electric services, schools and police stations, roads, airports, etc.

According to Fox (1994), as quoted in Yomi (2003) "Infrastructure is seen as including those social services derived from a set of public works traditionally provided by the public sector, to enhance private sector production and to allow for household consumption. They include services like roads, hospitals, schools, water supply, sewage, etc. All these services largely determine how healthy and prosperous an individual would be and how long he will live". The Oxford Advanced Learners Dictionary (2000) defines Infrastructure to mean basic system and services that are necessary for a country or an organization. Examples are buildings, transport, water and power supply, and administrative system. Donald (1972) defines Infrastructure as the physical structure and facilities that are developed or acquired by public agencies to enhance governmental function and provide water, power, waste disposal, transportation or similar services to facilitate the achievement of common social and economic objectives.

As seen above, the main characteristic in the definition involves physical features, facilities or utilities which are usually put in place by public involvement and expenditure, and are aimed at facilitating the efficient functioning of a society. As society develops, the need to provide basic infrastructure for the wellbeing of their inhabitants arises. Most of the Infrastructure are capital intensive in the procurement and 
perhaps also in their maintenance, and these services are usually provided by the different levels of government in the federation although private sector participation is now gradually becoming noticeable due to the liberalization policy of some aspect of the national economy by the present administration (Iseh 2003).

Infrastructural development refers to the bringing into existence of the basic amenities and services which must be in place for a particular activity or pursuit. However, no nation can boast of significant development or an enhanced economy without providing the basic Infrastructure for the citizens' well-being. Amis and Kumar (2000) argued that Infrastructure helps individuals cope with the different dimensions of poverty. It follows therefore, that whenever people are deprived of basic infrastructure, the result is impoverishment. It also follows that cities with the greatest number of poor people are those whose citizens lack infrastructure the most.

\section{Infrastructure in the Pre-Colonial Nigeria}

The provision of infrastructure or what is known as social services began in the pre-colonial period among the various ethnic groups in Nigeria. Since social services are services rendered to individuals, groups or communities either by government or non-governmental or voluntary agencies in order to cope with the social problem and to enhance the welfare of people individually and collectively (Sanda 1981:8), then each of these ethnic groups in pre-colonial days devised means of enhancing the welfare of their people. It should be recalled that each of the tribes were organized under diverse rules that saw to the welfare of the entire citizenry.

The advent of colonialism brought a new phase in the provision of local services. It must be pointed out that the two principal objectives that guided the British policy in West African dependencies were associated with the idea of trusteeship and the welfare of the masses (Okafor 1981:5). The colonial administration also proposed that for self-government to be granted to Africans, they should be trained in the art of democracy. This necessitated Earl Grey in 1840s to advocate the creation of a system of municipal government and to use same to train the inhabitants of dependencies in civil responsibility. It was Grey's proposal that made Sir Cornelius Alfred Moloney, the administrator of Lagos colony from 1886-1890, to establish during his tenure, a Health Board in the colony. Specific social problems brought about new ordinances to combat them. For instance, new legislations were promulgated following the outbreak of post-world war I epidemics and the bubonic plague of 1924 in Lagos. Also the outbreak of fire in Lagos in 1877 led to the public ordinance which specified the space required between houses with thatches roots. This was put at not less than seven feet apart. By 1877, the first "inspector of Nuisance" was appointed and by 1897, Lagos had both a sanitary and medical department. During Governor Clover's term, an organization called Lagos Ladies League operated as a health organ to combat the rate of malaria (Iseh 2003).

The activities of the missionaries in the provision of infrastructure or social services cannot be forgotten to be mentioned here. Such activities complemented that of the British government who actually restricted her own social services in Nigeria because, it believed that each dependency must be self-supporting (Okafor 1981:38). The missionaries placed much emphasis on education and strove frantically to train the Africans under their care. One Mr Henry Vern, the famous CMS secretary brought into existence the "Native Agency Committee" which was dedicated to training out European artisans to work in African alongside the missionaries (Olusanya 1975:2), but as the northern Nigeria was closed to the missionaries because of the fear by the British government that they might pollute and consequently poison the minds of the northern against the British government, the impact of the missionaries became greatly felt in the south (Bamgbose 2003); especially in the provision of infrastructure/social services. These were all in attempt to provide the people with basic infrastructure, or what is called social services.

\section{Infrastructure Development in Nigeria Today}


In the words of Frank Iseh in his write-up, "urban finance and infrastructural development in Nigeria", edited by Yomi, pages 35-40; "urban infrastructure propels the socio-economic growth of a city. To be able to do this, not only should the physical structures be put in place, they must also be properly maintained. Also, they must always be seen to be in good performance conditions'. Key among urban infrastructure are electricity supply, water supply, road transportation, communication, drainage, sewage disposal, and housing.

\section{Electricity Supply}

Nationally, the supply of electricity has been the sole responsibility of the power holding Nigeria limited. Regular supply of electricity is very necessary for the all-round development of any nation. Aside domestic uses, commercial and industrial concerns need constant supply of electricity for their businesses. However, our electricity supply is characterized by frequent power cuts; sometimes some communities may remain without electric power supply for hours, weeks and even months (Iseh 2003). Owing to the 'epileptic' electricity supply, many consumers have resorted to using alternatives such as lantern, kerosene stove, gas lamps, and generators. The irregular supply of electricity has caused many industries or some other commercial concerns to produce below capacities and, in some extreme cases, fold up, thereby forcing many employees into the labour market. Also the use of these alternative sources of power supply have sometimes caused explosion resulting in loss of lives and properties.

\section{Water Supply}

One of the foremost needs of man for his daily survival is water. Realizing man's need for water, governments over the years have created one agency or the other to ensure adequate supply of water to the people. The agencies include several state water boards and corporations. Past water supply from public taps was free. According to Nubi (2002), government's inability to sustain the free lunch led to commercialization of water corporations, thus restricting water supply to people that could afford it at the commercial rate. Consumers who cannot afford the commercial rate have their supplies cut off. Irregular electric power supply has often been blamed by the water corporations for irregular water supply. He maintained that despite the commercialization of the water corporation, supply is still irregular and purchase of water and long queues at public taps (where any is found) and drawing of water from wells are common sight in many parts of Nigeria. Even where provision is made for public water supply, private arrangement are still made for boreholes and deep wells. However, drinking of water from these untreated supply sources have been blamed for frequent occurrence of typhoid fever, cholera and other associated diseases. Olawole (1997) argues that many taps are dry in the urban centre and water-borne diseases, which used to be synonymous with the rural areas in those days have now become prevalent and the scourge of the urban dwellers (Iseh 2003).

\section{Road Transport}

Road transport refers to the conveyance of people, goods and services from one place to the other via roads. In almost all urban centres, the road is the commonest means of transport. For the economic, social and political development of the urban centre, there is need for efficient and effective urban transport network. Towards the end of the military administration in the country in the 1990s, many of the intra-and inter-city road networks built during the oil boom of the 1970s had fallen into unimaginable state of disrepair. Hence, traffic congestion and accidents have become common sight in most urban centres, especially during the peak hours, thereby threatening their economic lives.

\section{Communication}


According to Iseh (2003), the importance of effective communication in the economy cannot be over emphasized. He said that communication is a verifying factor; it is a means of interaction between individuals, groups and even nations. Through effective communication, information, messages and ideas are easily conveyed from one place to another. Effective postal and telecommunications systems, including the telephone, telegraph, telex, cellular phones, postal services, and others will reduce the burden on the urban roads as many urban dwellers would be able to transact their businesses through the available communication systems rather than face the congested roads. In such a situation, commercial and industrial lives can operate more efficiently. Telecommunication today has taken a new dimension with the liberalization policy of the industry by the federal government to break the monopoly of NITEL, the federal government's agency responsible for providing telephone services. Before now, the poor performance of NITEL has contributed to the public outcry for its privatization and liberalization of the telecommunication sector. Before now, with NITEL, solely providing telecommunication services, it was not unusual for prospective subscribers to wait for several months or even years to be allocated telephone lines while those already enjoying such services are often interrupted with frequent disconnection even when they are not in arrears of bills (Iseh 2003).

\section{Drainage}

A major problem which confronts many urban centres today in Nigeria is yearly flooding after every down pour. This is caused by drainage canals which have been blocked purposefully by people carrying out unauthorized construction or by share negligence of the urban dwellers to clear the drainages of debris as well as dumping of refuse and sachets of water in the drainages; or total abuse of drainages in the consigned neighbourhood. Uncoordinated physical planning, especially in some slums and new development centres within the suburban areas is another important contributor to flooding.

\section{Sewage (Solid) Disposal}

The incessant accumulation of solid waste along the roads in towns and cities in Nigeria is alarming. Waste deposit, especially along streets and even along highways has become an environmental hazard. In some urban centres, there may be no designated spots to deposit the wastes for their onward disposal; therefore, people throw them about indiscriminately, even into the drainage canals, hoping that the flood water will carry the waste away when rain falls. Unfortunately, some of these waste deposits end up clogging the drainage channels and turning the flooding of our roads into permanent scenery in the environment. However, in Akwa Ibom state, specific spots are created a long road and some streets to facilitate the collection and disposal of waste by refuse disposal contractors in recent times.

\section{Housing}

Shelter forms part of the three basic needs of man. Therefore, the shortage of decent and comfortable accommodation in urban areas is one of the greatest problems confronting urban dwellers, especially in the low-income neighbourhoods. This situation is factored by many contributors which include:

1. The high cost of housing development.

2. The problem of securing land.

3. Poverty

4. The difficulties associated with obtaining appropriate titles.

5. Over population and the resultant pressure on available accommodation, and

6. Corruption in government land allocation.

Due to this shortage of housing accommodation in most urban centres in Nigeria, many urban dwellers, 
especially, the low-income groups now resort to houses characterized by overcrowding, noise pollution, frequent change in use, insecurity, over utilization of available facilities, poor drainage system, inaccessibility, absent/inadequate recreational facilities, high rentals, poor maintenance, substandard construction and inadequate services. In the words of Iseh (2003), the above description of the state of some of urban infrastructure merely illustrates the problem; the reality in most urban centres in Nigeria is much worse than we have indicated here'.

\section{Constraints of Effective Service Delivery of Urban Infrastructure In Nigeria}

From the analysed situation above, it could be observed that there is general public outcry over the poor conditions of our urban infrastructure. From the roads, especially in the south-south geopolitical enclave where the study area is found, to postal services; from the drainage/sewage disposal systems to electricity and water supplies; and housing the story remain the same. According to Iseh (2003) a survey has shown some features among the major causes of the poor infrastructural performance in urban centres in Nigeria to include:

\subsection{High Cost of Providing Urban Infrastructure:}

The capital intensive characteristic of urban infrastructure provisions makes it to be left in the hands of the government for its development. Nubi (2002) however observed that funding of the urban infrastructure has always been a major concern of all tiers of government and procurement has always been limited by available fund. Funding the provisions of telephone, electricity, or many housing schemes, for instance will require a lot of capital. With our low income per capita, only a limited number of persons or organizations may venture into the provision of such services as the generation and distribution of electricity. Lawal (1997) presented a similar scenario when he said that without well organized and efficient housing finance system, it is difficult to mobilize substantial financial resources for channelling funds into the housing sector. During the era of the oil boom, the three tiers of government invested substantial sum of money into our urban infrastructure such as roads, telephone services, stadia, and electricity supply, but by the 1980s and 1990s, following economic depression of the time in the country, the maintenance of the existing facilities became difficult, making substantial additional provisions to meet the increasing demand for them became a great task. Due to financial limitations, many projects that had commenced were later abandoned or developed in piece mill, while in some other cases; the pace of work was slowed down in order to accommodate the lean financial resources available.

\subsection{Inadequate Budgeting by the Government:}

Though the fund for any contemplated development might be available, if adequate budgeting is not made, the project might not see the light of the day after all. Therefore, unless adequate financial resources are budgeted for a project, it will normally be almost impossible for funds to be withdrawn for such unbudgeted projects.

\subsection{Poor National Maintenance Policy}

The national maintenance policy of our urban infrastructure is the general attitude of the people to the culture of maintenance itself. It would appear that generally, people are more interested in the initial capital cost of developing or providing the infrastructure without paying due attention or making adequate provision for the running/maintenance costs of such facilities. Analysing this problem, Ahmad (1997) asserts thus- "the major maintenance constraints are institutional and that maintenance is not recognized in the national policy 
making process; it is not reflected in budgetary or resource allocation process in spite of the expected contribution of the national assets to the achievement of the nation's macro-economic objectives". Furthermore, it is known that the non-availability or inadequacy of appropriate spare parts in the country and the difficulty of importing them add to the problems of maintenance. This poor maintenance culture often leads to the breakdown of facilities. It is no surprise therefore to note that this point has been repeated severally in many different literatures concerning development. Omirin (1986), in this direction particularly observed that "Nigeria is generally considered a country where nothing works and that water and electricity are irregular, roads are in bad state of repairs, streets and neighbourhood are always flooded in rainy season, refuse dumps litter the neighbourhood, while telephones have become mere monumental pieces of furniture instead of a mean of communication". As a result, these urban infrastructure perform below expectation despite the huge sums of money invested to provide them and they have remained a great burden to the national reserved.

\subsection{Undue Political Interference/Uncoordinated Good Policies}

Undue interference and poor coordination of government policies can have negative influence on urban infrastructure. The case of the abandoned metro line project may be illustrative here. The proposed project, if implemented, would probably have eased urban transportation problem in Lagos. But the successive military administration abandoned it. The alleged heavy financial cost was one of the reasons given for stopping the project by the military administration which took over power in Lagos state for instance. It is the same story all over the country, each successive government maintains a negative attitude to projects began by its predecessor and the chain continues, leaving the country with thousands of uncompleted and abandoned projects.

\subsection{Failure/Unwillingness of Government to Liberalize Policies Towards Urban Infrastructural Services}

In the past, government for certain reasons refuses to show reasonable interest in allowing private sector participation in our urban infrastructural provision (Iseh.2003). The burden of providing urban infrastructure was concentrated on the three tiers of government, even though the government lacked the funds to live up to expectation in most cases. But the present government in Nigeria has made a paradigm shift through privatization by allowing private participation in infrastructural provision. This case is observed in Akwa lbom state where the present government in the state initiated a joint venture with power holding Nigeria and some foreign private investors to come up with the Ibom power plant project for the generation and distribution of electricity in the state and beyond. In the telecommunication sector, giant strides have been made also in this direction. For instance the immediate past administration was the first state government to partner with a telecommunication outfit (Econet wireless) to liberalize its services especially in the rural communities. In the road sector, the present governor of Akwa Ibom state (Governor Godswill Akpabio) is initiating private participation in road construction and maintenance through "Operation Zero Pothole" initiative. In the area of solid waste disposal or management, private sector involvement has come to stay in Akwa Ibom state.

\subsection{Public Attitude to Urban Infrastructure}

The notion that public property is nobody's property" is still fresh in the minds of people in the country. This particularly account for the nonchalant attitude of the public towards public property. Aibangbee (1997) states that "it is not uncommon, for instance, for the pipes laid for the distribution of water to be uprooted by road construction workers without any care to repair them, thereby causing avoidable wastage. Also, the fact that the public sees nothing of the efficient services expected of the tax it pays makes it indifferent to the need, of the government and causes it to develop an attitude of total disregard for government infrastructure". 
Mischievous members of the public are always cannibalizing on electric and telephone cables and, while such infrastructure is being vandalized and stolen, and Nigerians turn the blind eye.

\subsection{Corruption in the Public Sector of the Economy}

Nigeria is rated as the second most corrupt nation in the world, after Bangladesh, according to Vanguard newspaper of Thursday, 29 August, 2002. This singular fact poses a big problem in the country. The highclass corruption in the public sector of our economy affects the provision and maintenance of urban infrastructure. These corrupt practices may take various forms. Examples, it is not uncommon to inflate by a great margin the budgetary provision for the procurement of urban infrastructure, only for the facilities not to be procured at all. At other times, very inferior materials are acquired at exorbitant prices, with the result that the life cycle of the item or project may be terribly shortened. Similar problem affects the maintenance of urban infrastructure. Often fictitious and highly inflated maintenance bills may be raised, yet poor standard jobs may be done and in some cases, no jobs are executed at all even though maintenance contracts to firms in which they have direct or indirect interest. The conservative 10\% kickback that the immediate postindependence policy makers took has given way to brazen robbery that makes the actual cost spent on project peanuts compared to the total sums paid out on them.

\subsection{Poor Conditions of Services in the Public Services}

Poverty, no doubt contributes to gross inefficiency, corruption and low productivity. Prior to the civilian administration of President Olusegun Obasanjo, the annual total remuneration for the average public servant was very poor. The income, when contrasted with the inflationary trends in the country as well as the nature of our African extended family lineages with its attendant social/financial responsibilities, financially incapacitates the average Nigeria public servant and limits his ability to meet his socio economic responsibilities. All these tend to make corruption seemingly attractive to him and may fall on account of such temptation. Other constraints to effective delivery of urban infrastructure may include the absence of effective physical development plan in some of our urban centres. A city without effectively planned and development control programme may occasion haphazard developments thereby creating problems when it becomes necessary to site new infrastructure. Also, institutional conflicts and their consequences can cause ineffective infrastructural delivery system. These conflicts may be vertical, that is, between different levels of government, for instance the federal, the state, and local governments. It may also be horizontal, that is, occurring within the same level of government. These conflicts could result from conflicting interests such as laying claim to the same piece of land by different bodies or authorities in the desire to provide services. If uncontrolled, such conflict could lead to improper coordination resulting in inefficient urban infrastructural services.

\section{Factors Affecting Property Values}

If an estate agent or a real property owner is asked, what the factors that affect property values are, the list could be endless. However, there are several factors which affect property value and should be considered in any transaction involving property interest. Some of those factors include the curb appeal, the neighbourhood the property is found, and the infrastructural facilities around or close to the property, the economic situation in a place, etc.

The curb appeal of a home is basically the first thought that people have as they are driving by a property. (http.//www.ehow.com/info_7754088_factor.affecting-property-values.html -2012). This comes as a result of the finishes as well as the various services found there which synchronizes with what is looked for at a time in the property of a particular nature (taste); in addition to the presence of garden or lawn within the 
premises. The neighbourhood is one of the important factors that affect property value. This is not something one can always do too much about. If one lives in a nice neighbourhood, the better; if not, one may want to think about rallying all of the neighbours together to make the neighbourhood look a little nicer. Maybe one can plan a clean-up day and have everybody do their part by cleaning or helping the elderly neighbours who are not able. The most important of all factors, which affect property values in most cases, is the availability of infrastructural facilities around or within the neighbourhood where a property is located. The general economic happening in a state affects the values of property within the state. This is a product of the demand and supply which involves the interplay of other economic factors aside those mentioned above.

\section{The Impact of Infrastructure Provision on Property Values}

There are no major writers or analysts who reject the relationship between infrastructure and economic development. Often the concept of infrastructure investment and economic development are considered one and the same variable. Since economic development is universally connected with increasing property values near the infrastructure projects, there is also a clear relationship between increases in public investment and local property values. In the modern western world, infrastructure usually is reduced to roads, bridges, water and sewer services. In the developed world, things like security, health care and recreation are often included. However infrastructure is defined, it is the fundamental condition for economic development. (http://www.ehow.com/infor_7936264_effect- infrastructure-development-property-values.html - 2012). Its network of services usually provided by the state that makes increasing economic development possible. Professor Janet Rivers and Professor Michael Heaney have connected infrastructure investment to all facets of economic development. This almost always includes an increase in property values, which is not a problem since the increase is always offset by increasing opportunities and incomes in the general vicinity. The closer a residential area, for instance, is to new infrastructural projects, the higher the increase in its values. In addition, Rivers and Heaney also found that the reverse relationship is true. Falling infrastructural investment is closely related to falling property values. They go so far as to hold that, decaying or neglected infrastructure is a major determinant of economic decay and recession (Rivers and Heaney, 1995). This relationship also exists in the developing world in which Nigeria is not left out. Adebayo M. A. of the University of Lagos found strong relationships between property values, economic development and infrastructural development in Lagos, the commercial capital of Nigeria. Not only is there a connection between public investment and the financial values of local housing, but people are clearly willing to pay more for a house or business if they know there is, or was, substantial public effect in that people are willing to invest in an area if they consider they are a government priority. A situation which is not different from other parts of the country and Akwa Ibom state in particular shares in the similitude. When infrastructural development falls off due to tight budgets or has of public interest, the implication is that property values fall, and these fall because external investment falls. The most economically active people move out of an area when public investment is neglected. Furthermore, the basic transaction costs of infrastructural neglect begin to increase, making it less profitable to do business in that area. The policy implication is that public investment is necessary for economic development, profitability and economic progress in a given area.

\subsection{Infrastructure Provision Drives Property Investment}

In New York, a study assessing the impact of property proximity to light rail transit stations on residential property values was conducted. According to the study, for homes located in the study area, every foot closer to light rail station increases average property values by $\$ 2.31$ (using geographical straight line distance). This implies a positive relationship between residential property value and distance to a transit station being an infrastructure. According to the Guateng provincial government, objectives for certain areas surrounding Gautrain stations include increasing residential densities, promoting retail and office activity and improving 
pedestrian links in the vicinity, all of which are likely to increase property values. http://thepropertytimes.co.Za /2011/03/infrastructure-development-driven-property-investment.html.

The scenario presented above is not different from what is observed in Akwa Ibom state generally. Properties around newly developed infrastructure are seen to have increased value in recent past compared to what used to be before. For example, around the new federal prisons located at Ikot Ekpene, the International Airport, Uyo; Ibom Tropicana five star hotel, Uyo, Le Meridian Ibom Hotel and Gulf Resort, Uyo; the Akwa Ibom State University, Mkpat Enin; to mention a few, and the associated link up of the entire neighbourhood with tarred road, land values as well as residential property values have all gone up around these vicinities

\subsection{The Impact of Parks on Property Values}

Most people enjoy the benefit of open park land near their homes. While the aesthetic and environmental values of parks are easily recognized, their economic value is sometimes overlooked. In fact, studies have shown that parks create a positive economic impact by increasing nearby property values. http://www.ehow.com/about_5306175_impact-parks-property-value.html. Historically, support of park development has intuitively felt that parks increase nearby property values. More recently, these views have been confirmed through statistical studies. For example, a study conducted in Portland, Oregon, in 2000 found that a group of parks had a positive impact on the values of properties within a distance of 1,500 feet. Another study conducted on a number of parks in Dallas in 2001 found that homes facing a park were worth 22 per cent more than homes located half a mile away from a park. The effect is that people enjoy the benefit and natural beauty that a park offers and so they naturally desire property that is located near a park. This increase in demand translates to an increase in property value. Increased values lead to increased property taxes, which pay for the cost of developing the park. This means that over the long term, a park will most likely pay for itself. Park also attracts desirable residents such as retirees to the area. This effect may also impact property values positively because safe, friendly communities are very desirable places to live. While parks have been shown to increase nearby property values generally, there are factors that may affect the magnitude of the increase. For example, it has been observed that parks designed for passive use have a greater impact than parks designed for active use. Also if there is another park within a reasonably close distance, the addition of a second park may not have as great an impact on property values. It is also reasonable to assume that the size and layout of a park will have some impact on the amount by which nearby property values increase. (http://www.ehow.com/about_5306175_impact-parks-property-value.html.)

\subsection{The Impact of Landscaping on Property Values}

From the book "Home outside: creating the landscape you love" by Julie Moir Messervy (2009) well designed front and back yard has the potential to add 20 per cent to home's value. Tidy landscaping means ensuring the walkway is clear of debris and cracks in the pavement, the lawn is groomed by the grass being kept green and short or the rocks evenly distributed, and the trees do not block the views of the home. The economic effect of landscaping could be a "Spillover" effect. Robert Carbaugh (2000) explains the meaning of this phrase in his book, "Contemporary Economics" - a spill over effect is a benefit or cost issued to people other than the primary producer of a service. In this case, improving the landscape of your home improves the image and reputation of the neighbourhood. Furthermore, the neighbours might be compelled to improve their own landscape when they see how much nicer your home appears as a result of the renovations. However, neighbours are equally likely to issue a complaint to you or with the home owners association if you fail to keep your yard up to the standards in the neighbourhood. Neglecting the appearance of your yard could create a negative externality for your neighbours. (http://www-ehow.com/info_7755419_economiceffects-landscaping-property-values.html.) William Thompson, author of the book, "Sustainable Landscape 
Construction" contends that the effects of landscaping on property value are unproven. Because the benefits are not easily quantified and different projects have varying cost, specifying the exact increase in property value is difficult; the property value increase is estimated between five per cent and twenty per cent. (http://www-ehow.com/info_7755419_economic-effects-landscaping-property-values.html.)

\subsection{The Impact of Private Schools on Property Values}

The location of private schools can increase property values if viewed as significant community assets. Private school, can affect property values either positively or negatively. The impact may be reflected in home prices, assessments and/or local tax levies and rates. The nature of the impact depends on the reason why these schools developed in the area. It may also be influenced by certain characteristics of the local population. Many communities support excellent school but still offer parents the option of private schools which is especially common when the local population is affluent or where there is a strong demand for religious education. In both of these cases, private schools can increase local property values because people make a choice to pay more for a range of quality educational options. The positive effect may be heightened if the private institutions offer pre-school classes or other types of specialized programmes typically unavailable in public schools. Sometimes private schools are developed in response to perceived shortcomings in a community's public education. For examples, people may believe there are overcrowded or deteriorating school buildings, overly large student-teacher ratios, poor standardized test scores and/or low graduation rates. These kinds of perception can hurt property values in two ways. First, demand and prices will be reduced when home buyers who are unable to afford private schools go elsewhere. Second, taxes may need to be increased to correct the public schools deficiencies. http://www.ehow.com/fact-effect-privateschools-property-value.html.

\subsection{The Impact of Road Infrastructure on Property Value}

The construction of road ways is a major factor in making life easier in any area, particularly areas farther away from the urban centre. For this reason, road construction can be a major boon for property values, both residential and commercial. At the same time, if road construction leaves areas excluded at the benefit of others, it can lead to lower property values. (http://www.ehow.com/list_7592567_effects-road-constructionproperty-values.html.) Moreover, the effect of highway infrastructure upon property values vary according to the type of construction that is already in place or currently being proposed. Roads that provide access to communities and business for 'smart' growth will increase property values. Roads that serve as barriers, or redirect traffic away from particular areas, will cause property values to fall. Secondary Route; for example, which provide access into an area by signed traffic lights increase property values. Newly constructed and well-maintained highways and side streets are good places for commercial and residential development. Principal Route; the impact upon property values related to principal routes, such as express ways and multilane highways is mixed. Interstates have been tied to both economically vibrant corridors and urban blight. Highway Exit; businesses often cluster around highway exits that carry traffic off and onto a major freeway. The highway inter change provides convenient access to the area, which promote growth. Home builder typically advertise close proximity to major highway exits as selling points. Barrier; large highways can serve as barriers to divide regions, economically. The author of "The Power Broker"- Robert Caro, cites Robert Moses' design of the Cross Bronx Expressway as the direct cause for uprooting stable communities and isolating the South Bronx as a notorious inner-city ghetto from the rest of New York City. Redirecting Traffic; property values fall when new roads are built that redirect traffic away from an area. Traffic is more likely to use the main highway, than patronize businesses along what have now become back roads. Meanwhile, development increases alongside new routes that direct traffic into an area. Property values advance when communities grow (http://www.ehow.com/facts_5526410_effects-road-infrastructure-property- 
value-html.)

\section{Methods and Procedures}

In the research, a survey design was used to obtain information concerning current status on the imperative of infrastructure development on property values. This was directed towards determining the nature of the situation as it existed at the time of the study. The aim of this design was to describe what existed with respect to variables, or conditions in the situation. The target population of the study comprised of the entire property owners in eket, Ikot Ekpene and uyo towns, representing the three senatorial districts of the state, who have titles to their properties duly registered in their various Land Registry and their building plans approved by the state government in the past six years, starting from 2007. To this end, a total of eight hundred and forty seven people were used in population. More so, some estate firms in the state were also studied to ascertain trend in property values for the period under study. Yare Yamane's Formula for finite population was used to determine the sample size from the population. This gave a sample size of two hundred and seventy two respondents. The formula is as follows:

$$
\mathrm{n}=\frac{\mathrm{N}}{1+\mathrm{N}(\mathrm{e})^{2}}
$$

Where, $\mathrm{n}=$ the sample size; $\mathrm{N}=$ the finite population; $\mathrm{e}=$ level of significance

(0.05 limit of tolerance error); 1 = unity (a constant)

The instrument used in the collection of data was a structured questionnaire. The questionnaire was framed in a way to contain the specific questions relating to the subject where answers were solicited from the respondents. The questionnaire had specific items structured to bring out required information for the research. The responses were made on a four point scale, thus: strongly agreed (SA), agreed (A), disagreed (D), and strongly disagreed (SD). The researcher administered the questionnaires randomly to respondents. Two hundred and seventy two questionnaires were distributed randomly, but two hundred and seventy turn in for analysis. Data were also obtained through oral interviews, as well as records of the trend of values from Estate firms in Akwa Ibom State. Statistical mean was used to answer the research questions in order to accept or reject the research questions as the case may be.

\section{Results}

Statistical mean was used to ascertain the acceptance or otherwise of the questionnaire items. An item was only accepted if it scored at least 2.5 on the four point scale mean value (x). Items which scored below 2.5 were rejected. The analysis of the collated data presents the result in the tables below:

Table 1: The relationship between infrastructure development and property value:

\begin{tabular}{|c|l|c|c|c|c|c|c|c|}
\hline \multicolumn{1}{|c|}{ Statement } & $\begin{array}{c}4 \\
\text { SA }\end{array}$ & $\begin{array}{c}3 \\
\text { A }\end{array}$ & $\begin{array}{c}2 \\
\text { D }\end{array}$ & $\begin{array}{c}1 \\
\text { SD }\end{array}$ & $\sum \mathrm{fx}$ & $\mathrm{X}$ & Remark \\
\hline 1 & $\begin{array}{l}\text { Development of infrastructure gives rise to the choice of } \\
\text { site for property development }\end{array}$ & 720 & 150 & 40 & - & 950 & 3.80 & $\mathrm{~A}$ \\
\hline 2 & $\begin{array}{l}\text { Provision of infrastructure generates higher property } \\
\text { value }\end{array}$ & 600 & 150 & 100 & - & 850 & 3.40 & $\mathrm{~A}$ \\
\hline 3 & $\begin{array}{l}\text { Provision of infrastructure attracts most people to } \\
\text { accept settling at a given neighbourhood }\end{array}$ & 800 & 144 & - & - & 944 & 3.78 & $\mathrm{~A}$ \\
\hline 4 & $\begin{array}{l}\text { Lessees prefer properties located where infrastructure } \\
\text { development are comparatively optimal }\end{array}$ & 600 & 300 & - & - & 900 & 3.60 & $\mathrm{~A}$ \\
\hline
\end{tabular}


From the table above, the result shows that there is strong relationship between infrastructure development and property values as all the questionnaire items scored above the minimum point of 2.5 on the scale

Table 2: Factors which influence property value:

\begin{tabular}{|c|l|c|c|c|c|c|c|c|}
\hline \multicolumn{1}{|c|}{ Statement } & $\begin{array}{c}4 \\
\text { SA }\end{array}$ & $\begin{array}{c}3 \\
\text { A }\end{array}$ & $\begin{array}{c}2 \\
\text { D }\end{array}$ & $\begin{array}{c}1 \\
\text { SD }\end{array}$ & Ifx & X & Remark \\
\hline 5 & 480 & 390 & - & - & 870 & 3.48 & $\mathrm{~A}$ \\
\hline 6 & $\begin{array}{l}\text { Property value can be enhanced by the } \\
\text { neigbourhood it is found } \\
\text { fropersibility value }\end{array}$ & 760 & 165 & 10 & - & 930 & 3.72 & $\mathrm{~A}$ \\
\hline 7 & $\begin{array}{l}\text { The general economic situation in the country affect } \\
\text { property value }\end{array}$ & 760 & 150 & 20 & - & 930 & 3.72 & $\mathrm{~A}$ \\
\hline 8 & $\begin{array}{l}\text { The individual appeal of the property can improve its } \\
\text { value }\end{array}$ & 200 & 600 & - & - & 800 & 3.20 & $\mathrm{~A}$ \\
\hline
\end{tabular}

In the same vain, observed from table 2, it could be seen that the entire questionnaire items scored above the minimum score. This was an indication that showed that the mentioned characteristics in the questionnaire items were among the factors which influence property values. They include, but limited to:
a. Provision of infrastructure.
b. Good neighbourhood.
c. Property's individual appeal, and
d. The general economic situation in the country.

\section{Conclusion}

The research has assessed the imperative of infrastructure provision on property value in Nigeria, a case study of Akwa Ibom State, using three research questions and statistical mean to answer the research question. In essence, the imperative of infrastructure provision on property value can be concluded thus:
a. Increased property value
b. Suitable site selection for property development/investment
c. Promotion of good neighbourhood
d. Healthful settlement engendering
e. Economic empowerment

\section{References}

Aibangbee, S. S. (1997) Functions of Urban Infrastructure in National Development. A paper presentation at the $27^{\text {th }}$ annual conference of the Nigerian Institution of Estate Surveyors and Valuers at Premier hotel, Ibadan.

Adebayo, M. A. (2006) The State of urban infrastructure and its effects on property values in Lagos. University of Lagos, Nigeria

Akinola, S.R. (2007) Coping with infrastructure deprivation through collective action among rural people in Nigeria. J. African Studies.16, p30-46

Amis D. And Kumar (2000) Urban economic growth, infrastructure, and poverty in India: Lessons from Visakhapatnam, environment and murbanization. Vol. 12 (1)

Bello, I. B (1996) Electricity for rural development. Development outlook (6): November.

Denis, L. E (JD) and William E. (JD) (2007) Real Estate Encyclopedia. McGraw Hill. New York.

Donald, C.S (1974) Professional education in public works/environmental engineering administration. 95 $5^{\text {th }}$ Edition. Chicago: American public works and association 
Fox, W. F (1994) Strategic options for urban infrastructure management. Urban Management programme (UMP) Paper 17, The World Bank, p7.

Frank Iseh (2003) The state of urban infrastructure in Nigeria. Atlantis Books, Ibadan. Nigeria

Janet, M. R and Michael, T. H (1995) Infrastructure and local economic development. University of Michigan. U.S.A.

Julie Moir Messervy (2012) Home Outside: creating the landscape you love. Quoted from: http://www-ehow.com linfo_7755419_economic-effects-landscaping property-values.html.

Julius A. B. (2009) Effect of infrastructural facilities on the rental values of residential property. Journal of social sciences 5(4): p332-341

Lawal, M. I (1997) Principles and practice of housing management. Festac Town, Lagos: IICO Books and publishers

Mabogunje, A. L (1993) Infrastructure: The crux of modern urban development.Urban age,3 ;p3-3

Nubi, W. and Goodall (1974) Aspect of land economics. London: The Estate Gazette Limited.

Okafor, S.O. (1981) Indirect rule and rural development of central legislature in Nigeria. Lagos. Nelson

Olawole A.(1997) Urban infrastructure management and vision 2010. Paper presentation at the annual conference of Nigerian Institution of Estate Surveyors and Valuers at Premier hotel, Ibadan.

Omirin, M.M. (1986) Guideline for Effective Maintenance of the Public Infrastructure in Nigeria. Journal of Nigerian Institution of Estate Surveyors and Valuers. 10 (2).

Oxford University Press (2000) Oxford Advanced Learner English Dictionary

Robert Cabaugh (2012) Contemporary economics. Quoted from: http://www- ehow.com/info_7755419_economic-effectslandscaping property-values.html.

Sanda, A. O. (1981) The nature of social services and the evolution of social policy in Nigeria. In: The administration of social services in Nigeria: The challenges to local government, lle Ife: Local Government Training Programme, University of Ife

The Vanguard Newspaper (2002) Thursday, 29th August publications.

William Thompson (2012) Sustainable landscape construction. Quoted from: http://www- ehow.com/info_7755419 economic-effects-landscaping-property-values.html.

Yomi Fawehinmi (2003) Urban finance and infrastructure development in Nigeria. Atlantis Books, Ibadan. Nigeria. 
